\title{
KEBIJAKAN LUAR NEGERI NAJIB RAZAK TERHADAP KONSOLIDASI THAILAND DAN GERAKAN ALIANSI SEPARATISME ETNIS MELAYU DI THAILAND SELATAN DI TAHUN 2013-2016
}

\author{
Hardi Alunaza SD \\ Prodi Ilmu Hubungan Internasional Universitas Tanjungpura \\ hardi.asd@fisip.untan.ac.id \\ Retno Riyanti Sastro Amijoyo \\ Prodi Ilmu Hubungan Internasional Universitas Tanjungpura
}

\begin{abstract}
This paper aims to discuss Malaysian foreign policy in influencing the movement of separatism in Southern Thailand by the ethnic Malay alliance. The dynamics of separatism in Southern Thailand is the result of a process of conflict between religious groups and the harmonious relations between the majority and minorities. In this conflict, Malaysia is a facilitator, seen from various visits and efforts taken by Malaysia to create peace in the region of Thailand. This paper will focus on several matters related to how rational actors influence the movement of separatist movements in Southern Thailand and how the prospects for peace and consolidation after a meeting between the Thai government and consultants representing the alliance of separatism. The method of this paper uses descriptive methods with a qualitative approach in analyzing the phenomema. The technique of collecting data is done through various literature, journals, articles, and reading materials that are related to the issues to be discussed. This paper will be focused on two political angles, namely; (1) Direction of Najib Razak's foreign policy in 2013 (2) Direction of foreign policy for Najib Razak in 2016. The result of the discussion of this paper is through the government of Najib Razak, Malaysia consolidates Thailand with steps to resolve conflict namely peacemaking (reconciliation) and peacebuilding (social reconstruction).
\end{abstract}

Keywords: Foreign Policy, Rational Actors, Separatism 


\begin{abstract}
Abstrak
Tulisan ini bertujuan untuk membahas kebijakan luar negeri Malaysia dalam mempengaruhi pergerakan separatisme di Thailand Selatan oleh aliansi etnis Melayu. Dinamika separatisme di Thailand Selatan ini merupakan hasil dari proses pertentangan antara kelompok kepercayaan dan hubungan yang tidak harmonis antara mayoritas dan minoritas. Dalam konflik ini Malaysia berkedudukan sebagai fasilitator, terlihat dari berbagai kunjungan dan upaya yang di tempuh Malaysia demi terciptanya perdamaian di wilayah Thailand. Tulisan ini akan difokuskan dalam beberapa hal yang dikaitkan bagaimana aktor rasional berpengaruh terhadap pergerakan gerakan separatisme di Thailand Selatan serta bagaimana prospek perdamaian dan konsolidasi pasca pertemuan antara pemerintah Thailand dengan konsultan yang mewakili aliansi separatisme. Metode penulisan paper ini menggunakan metode deskriptif dengan pendekatan kualitatif dalam menganalisis fenomena. Teknik pengumpulan data dilakukan melalui berbagai literatur, jurnal, artikel, serta bahan bacaan yang berhubungan dengan permasalahan yang akan dibahas. Tulisan ini akan difokuskan oleh dua sudut politik yakni; (1) Arah kebijakan luar negeri Najib Razak pada tahun 2013 (2) Arah kebijakan luar negeri Najib Razak pada tahun 2016. Hasil dari pembahasan tulisan ini adalah melalui pemerintahan Najib Razak, Malaysia mengonsolidasi Thailand dengan langkah penyelesaian konflik yaitu dengan peace making (merekonsiliasi) dan peace building (rekonstruksi sosial).
\end{abstract}

Kata Kunci: Kebijakan Luar Negeri, Aktor Rasional, Separatisme 


\section{Pendahuluan}

Pada awalnya wilayah Thailand Selatan seperti Narathiwat, Patani dan Yala merupakan bagian dari kerajaan Melayu Patani. Namun, pada 1902 pada masa kemunduran kerajaan Melayu Patani disepakati traktat Anglo-Siam antara pemerintah Siam dan Inggris, yang berisikan bahwa wilayah Patani Raya bukan merupakan kerajaan tersendiri lagi, tapi menjadi wilayah kerajaan Siam yang mayoritas beragama Buddha dan memiliki kebudayaan yang jauh berbeda dengan kerajaan Pattani. Latar belakang ini menjadi konflik yang terjadi di Thailand Selatan, akibat adanya pertentangan antara kelompok agama. Heterogenitas agama yang kompleks dengan berbagai aliran dalam agama tersebut mulai dari kelompok berpaham sederhana hingga kelompok berpaham radikal, fanatik dan ekstrim. Kelompok faham radikal biasanya begitu sensitif dengan kelompok lain.

Selain karena agama, homogenitas suku membuat Thailand terpecah menjadi dua yakni kelompok mayoritas dan minoritas. (Melvin, 2007:5) Agama Buddha dan Thai (orang asli Thailand) dianggap sebagai mayoritas sedangkan agama Islam dan Melayu dianggap sebagai minoritas. Wilayah Thailand yang mempunyai kesenjanganan sosial antara pendatang dengan penduduk lokal juga memiliki potensi konflik berbahaya. Potensi konflik tersebut pecah setelah wilayah Selatan Thailand yang meliputi kawasan bekas Kesultanan Pattani dilanda krisis politik dan konflik bersenjata yakni Pattani, Yala, Satun, Songkhla dan Narathiwat (Andaya, 2001)

Salah satu kebijakan yang dilakukan kerajaan Siam adalah bangsa Melayu Pattani tidak diperbolehkan masuk ke dalam sistem politik nasional kerajaan Siam yang dipusatkan di Bangkok. Selain menerapkan kebijakan pemerintahan sentralistik, pihak kerajaan Siam menerapkan identitas nasional dengan semboyan trinitas (eta lak thai) yang hanya mengakui satu kebangsaan bangsa Thai, satu agama Buddha, dan tunduk para kekuasaan Raja. Dilihat dari dimensi sosial budaya, identitas semacam ini dapat dilihat sebagai bentuk pemaksaan ideologi yang dapat mencabut masyarakat Muslim Patani dari tradisi dan identitasnya. Karena diluar tiga unsur tersebut kemudian tidak dianggap signifikan dalam urusan campur tangan kekuasaan maupun dalam penentuan kebijakan negara. Etnis Patani yang tidak menginginkan adanya pencampuran kultur Budha dan Islam, menyebabkan munculnya keinginan untuk mendirikan Patani Raya.

Kejadian Krue Se dan Tak Bai di tahun 2004 menguatkan konflik ini 
menjadi yang justru didalangi oleh gerakan aliansi separatisme bersenjata. Membuat mata dunia tertuju pada Thailand, tidak terkecuali Malaysia yang berbatasan geografis langsung dengan wilayah konflik di Thailand Selatan. Malaysia terdorong untuk membantu Thailand meyelesaikan permasalahan konflik di Thailand tersebut. Ditambah lagi dengan kesamaan agama dan kebudayaan dengan masyarakat di Thailand Selatan. Tidak hanya itu Kesultanan Pattani yang pada sejarahnya merupakan alam Melayu menambah kuat dorongan Malaysia untuk membantu menyelesaikan konflik tersebut (Zamberi, 1993:25)

Akhirnya Malaysia melakukan upaya mengakhiri ketegangan gerakan separatisme di wilayah Thailand Selatan sebagai tindakan usaha Malaysia berkedudukan sebagai fasilitator dalam konflik ini. Berbagai kunjungan dan upaya yang di tempuh yaitu demi terciptanya perdamaian di wilayah Thailand. Dalam menyelesaikan konflik di wilayah Thailand Selatan memerlukan langkah-langkah untuk menyelesaikan konflik tersebut. Melalui pemerintahan Najib Razak, Malaysia melakukan penyelesaian konflik dengan peace making (mempertemukan atau merekonsiliasi) dan peace building (implementasi perubahan atau rekonstruksi sosial). Langkah ini tidak lancar begitu saja, upaya yang dilakukan Malaysia harus dilakukan berulang mengingat banyaknya hal yang harus dipertimbangkan.

Berdasarkan permasalahan diatas, maka penulis dalam hal ini bertujuan untuk menjelaskan fenomena separatisme di Thailand dan sikap yang diambil Malaysia dibawah kepemimpinan Najib Razakserta pemaparan "Seberapa besar kontribusi Malaysia dibawah kepemimpinan Najib Razak dalam aspek penetapan kebijakan luar negeri dalam menghadapi isu separatisme yang berkembang dalam ruang lingkup regional Thailand maupun internasional?". Tulisan ini adalah sebagai lanjutan dari tulisan sebelumnya terkait diplomasi Malaysia-Thailand dalam mengatasi gerakan separatis di Thailand Selatan pada tahun 2000. Tulisan tersebut menunjukkan hasil bahwa gerakan separatis di Thailand Selatan belum dapat diselesaikan karena masih adanya perlawanan hingga diberikan otonomi khusus atau kemerdekaan. Hingga tulisan tersebut terselesaikan, penulis menjelaskan bahwa hubungan diplomatik kedua negara masih renggang. Tulisan ini lebih fokus kepada kebijakan Najib Razak terhadap konsolidasi Thailand dan gerakan separatis yang beretnis Melayu di Thailand Selatan.

\section{Metodologi Penelitian}


Metode penelitian yang digunakan dalam penelitian ini adalah metode deskriptif dengan pendekatan kualitatif karena penulis inginmenggambarkan dan memaparkan fakta-fakta atau keadaan ataupun pemberontakan yang tampak dari gerakan aliansi separatisme di Thailand Selatan sebagai bentuk relevansi dengan suatu permasalahan separatisme baik dari sudut pandang yang teoritis maupun praktis. Yang dilanjutkan dengan interpretasi data sehingga dapat menjelaskan dan menganalisa permasalahan serta memberikan solusi bagaimana peran Malaysia dalam konsolidasi pemerintah Thailand dan gerakan aliansi separatisme di Thailand Selatan. Dilanjutkan dengan teknik analisis data yang menjelaskan pengumpulan data sistematis untuk mempermudah penulis dalam memperoleh kesimpulan. Begitu pula dengan teknik pengumpulan data dalam penulisan ini yaitu dengan cara studi kepustakaan (library research). Teknik ini mempermudah penulis untuk mencari dan mendapat informasi dari buku, literature, jurnal penelitian, serta website berita yang berkaitan dengan permasalahan yang dibahas dalam penelitian ini.

$$
\text { Dalam penulisan kali ini }
$$
menggunakan kebijakan luar negeri (Foreign Policy). Kebijakan luar negeri digunakan sebagai alat menganalisa negara untuk mengetahui tindakan negara dalam sistem internasional. Menurut Goldstein, kebijakan luar negeri merupakan strategi yang dapat diambil oleh pemerintah dalam menentukan aksi/tindakan mereka di dunia internasional (Goldstein, 1999:147). Di sisi lain Rosenau berpendapat bahwa kebijakan luar negeri merupakan fungsi dari proses tujuan negara yang disusun.Tujuan kebijakan luar negeri tersebut dipengaruhi oleh target yang dilihat dari masa lalu dan aspirasi untuk masa yang akan datang.

Tiap negara dalam mengambil sebuah kebijakan luar negeri pasti didasari oleh tujuan yang berbeda-beda. Satu hal yang pasti dilakukan oleh negara-negara di dunia dalam mengeluarkan sebuah kebijakan luar negeri adalah untuk memenuhi dan mencapai target yang berasal dari aktor rasional. Kebijakan luar negeri sering dikaitkan oleh pemenuhan national interest suatu negara dalam usaha memengaruhi negara lain dalam berbagai bidang seperti dalam bidang keamanan nasional, prestige, ekonomi dan hal-hal lain yang dapat membawa banyak manfaat bagi negara tersebut dalam menjalankan interaksinya dengan negara lain di dunia. Biasanya aktor rasionaltiap negara, dalam melakukan perumusan kebijakan luar negeri akan melakukan pertimbangan terhadap ketersediaan sumber daya yang 
ada dalam negeri maupun sumber daya negara yang menjadi target kebijakan luar negeri negara tersebut, hal ini dilakukan karena kebijakan luar negeri dalam sistem internasional hanya sebagai alat negara dalam memengaruhi aktor lain untuk tunduk dan patuh kepada kebijakan tersebut,hasil ikatan tersebut menghasilkan banyak benefits bagi suatu negara.

Dalam kasus Malaysia membantu penyelesaian konflik antara Thailand dan gerakan aliansi separatisme (gerakan pemisahan diri) di Thailand Selatan ini. Malaysia terdorong kuat karena keamanan negaranya terganggu akibat banyaknya kaum separatis tersebut lari ke daerah perbatasan Malaysia. Mengingat Malaysia dan Thailand berbatasan geografis daratan secara langsung, mempermudah kaum separatis keluar dan masuk melewati perbatasan tersebut. Akibatnya Malaysia mengeluarkan kebijakan luar negeri untuk membantu menyelesaikan konflik dan juga mengkonsolidasikan Thailand dan Thailand Selatan. Konsolidasi disini ialah penyatukan kembali Thailand dan Thailand Selatan. Melalui Najib Razak, Malaysia melakukan upaya penyatuan yakni dengan peace making (mempertemukan atau merekonsiliasi) dan peace building (implementasi perubahan atau rekonstruksi sosial).

\section{Pembahasan}

Sejarah terciptanya gerakan aliansi separatisme dan penanganan Thailand

Negara Thailand didirikan pada pertengahan abad XIV dengan nama Siam. Pada tahun 1939 Siam berubah nama menjadi Thailand. Dalam menjalankan negaranya Thailand memiliki sistem pemerintahan parlementer dengan bentuk pemerintahan monarki konstitusional dan kepala pemerintahan perdana menteri. Sejak tahun 1946 hingga akhir 2016, Thailand memiliki kepala negara Raja Bhumibol Adulyadej (Rama IX). Wafatnya Raja Bhumibol membuat tahta kerajaan harus diturunkan kepada Putra mahkota Pangeran Maha Vajiralongkorn yang merupakan satu-satunya putra Raja Bhumibol yang sekaligus menjadi pewaris tahta (Kompas, 2016).

Thailand terdiri dari penduduk yang memiliki agama yang beragam. Tercatat bahwa mayoritas penduduk Thailand memeluk agama Buddha yakni sebesar 54,5 juta (87,2\%), Muslim 7,5 juta (12\%), Kristen 0,45 juta $(0,72 \%)$ dan lainnya 0,05 juta $(0,08 \%)$ yakni Hindu, Konghucu, Sikh, dll. Thailand mengalami konflik internal dalam negaranya, ditandai dengan adanya gerakan aliansi separatisme 
di Thailand Selatan (Pattani Raya). Pada tahun 1902 terjadi aneksasi yang menyebabkan Pattani Raya jatuh ke kerajaan Siam (Thailand) dan terjadilah perjanjian Anglo-Siam pada 1909 (Melvin, 2007:5).

Inti dari isi perjanjian tersebut menyebutkan bahwa Pattani Raya (Thailand Selatan) bukan merupakan kerajaan Melayu lagi, tetapi sudah menjadi wilayah kerajaan Siam (Thailand). Hal ini berpengaruh pada wilayah Thailand Selatan yang dahulunya memiliki otoritas harus tunduk di bawah kebijakan kerajaan Thailand. Jika dilihat secara geografisnya, perubahan yang cukup signifikan terjadi pada wilayah Thailand Selatan yang pada awalnya adalah negara yang merdeka dan mayoritas kini telah berubah menjadi wilayah kerajaan Thailand yang minoritas (Yuniarto, 2005: 91).

Akibatnya perubahan tersebut munculah gerakan separatisme yang ingin memperoleh otonomi atau bahkan memerdekakan diri. Kesenjangan sosial, ekonomi dan pembangunan serta pendapatan perkapita penduduk yang melebar juga menjadi satu diantara penyebabnya yang menimbulkan kekecewaan dan kecemburuan social (Pitsuwan, 1989: 25). Keinginan kuat ini juga dikarenakan ketimpangan ekonomi, sosial, politik dan lainnya yang dialami masyarakat Thailand Selatan. Adanya dominasi elit politik oleh etnis Thai terhadap Melayu-Muslim dalam pemerintahan. Selain itu, berlakunya pendidikan sekuler juga membuat MelayuMuslim menjadi tersingkirkan karena setiap sekolah di Thailand diwajibkan menggunakan bahasa Thai. Masyarakat di Thailand Selatan yang mayoritas Melayu, menggunakan bahasa Melayu yang telah dipakai selama ratusan tahun dan masyarakat Thailand Selatan tidak fasih bahkan tidak mengerti bahasa Thai membuat rasa tersingkirkan semakin kuat (Fuston, 2006:56).

Ketimpangan itu mencapai puncaknya pada 2004, ditandai munculnya kebangkitan Melayu-Muslim. Akibat konflik ini tercatat lebih dari 1843 insiden terjadi di wilayah Thailand Selatan pada 2000-2004 (Jitpiromsri, 2006: 97). Jatuhnya korban dan kerugian yang dialami semakin bertambah, setidaknya lebih dari 4.300 orang terbunuh dan 7.600 orang terluka, selain itu 2.295 wanita menjanda dan 4.455 anak kehilangan orangtuanya (Aulia, 2011). Untuk mengatasinya pemerintah Thailand megeluarkan status darurat militer pada 30 Agustus 2005. Status militer tersebut memberlakukan penyadapan, penggeledahan dan penangkapan orang yang dicurigai melakukan aksi 
kekerasan/pemberontakan

mengacaukan situasi (Wibisono, 2007).

Disatu sisi penerapan status darurat militer tersebut menjadi sangat menakutkan di wilayah Selatan.

\section{Eksodus dan Kerjasama Thailand- Malaysia}

Akibat ketakutan tersebut maka terjadilah eksodus besar-besaran penduduk Thailand Selatan yang bergerak memasuki wilayah Malaysia untuk mencari perlindungan. Hal ini tentu saja dipengaruhi oleh jarak geografis yang dekat. Tidak hanya itu, gerakan aliansi separatisme yang dicari oleh pemerintah Thailand justru kerap ditemukan memasuki wilayah Malaysia. Tentu saja Malaysia khawatir akan keadaan tersebut. Kekhawatiran Malaysia dilator belakangi juga oleh beberapa hal, misalnya wilayah perbatasan yang sangat dekat dan menimbulkan ketakutkan bagi masyarakat Malaysia yang tinggal di perbatasan tersebut. Sebagai contoh ketika pembetontak Thailand Selatan diburu oleh pemerintah Thailand dan pada umumnya mereka akan melarikan dirinya ke wilayah perbatasan, bahkan hingga memasuki wilayah Malaysia. Tentu saja, kejadian ini dapat menimbulkan gangguan keamanan bagi penduduk lintas batas Malaysia. Begitu pula saat menyikapi eksodus 131 penduduk Thailand ke Malaysia menjadi dilematis sendiri bagi Malaysia. Pihak Malaysia ingin memberikan perlindungan sementara bagi penduduk tersebut, setidaknya hingga status darurat militer tersebut dicabut. Akan tetapi reaksi berbeda ditunjukkan oleh pemerintahan Thailand. Thailand mengeluh atas sikap Kuala Lumpur yang menerima 131 penduduk.

Sejak status darurat militer diberlakukan oleh Thailand pada 2005 yang mengakibatkan eksodus penduduknya ke Malaysia, hubungan Malaysia dan Thailand mengalami ketegangan hubungan diplomatik. Yang ditandai dengan saling kecam dan saling tuduh antara Thailand dan Malaysia. Pihak Thailand beranggapan bahwa setiap separatisme yang melarikan diri ke wilayah Malaysia akan mendapatkan perlindungan khusus dari Malaysia. Di sisi lain, pemerintah Thailand tidak terima karena Malaysia terlalu ikut campur dengan permasalahan Thailand. Sedangkan di sisi Malaysia menyatakan bahwa tidak ada dasar yang dapat membenarkan setiap aliansi atau negara untuk mengambil tindakan terhadap negara lain. Maka tercatat pada tahun 2005 hingga 2007 Thailand dan Malaysia mengalami ketegangan hubungan diplomatik terkait gerakan aliansi separatisme yang belum teratasi. Memasuki tahun 2007 hingga 
tahun 2009, kedua negara menyadari bahwa saling mengecam justru tidak akan menyelesaikan masalah.

Oleh sebab itu, baik Thailand maupun Malaysia mulai menjalin hubungan baik untuk mengatasi gerakan aliansi separatisme tersebut. Maka sejak itulah kedua negara mulai melakukan kunjungan dan membangun kesepakatan untuk mengatasi gerakan aliansi separatisme. Thailand dan Malaysia sepakat untuk memetakan rangkaian upaya sosial ekonomi untuk mengakhiri ketegangan dan gerakan aliansi separatisme di wilayah Thailand Selatan. Saat itu menurut menteri luar negeri Malaysia menyatakan bahwa ketegangan yang terjadi tidak terkait agama atau islam melainkan adanya perasaan teralineasi, ditinggal dan problem sosio-ekonomi (Tempo, 2011).

\section{Pemetaan Rangkaian Upaya Malaysia}

\section{Konsolidasikan Thailand}

Rangkaian pemetaan upaya untuk mengakhiri ketegangan gerakan aliansi separatisme di wilayah Thailand Selatan sebagai bentuk usaha Malaysia dalam membantu meyelesaikan konflik ini. Dalam menyelesaikan konflik ini diperlukan langkah-langkah untuk menyelesaikan konflik tersebut, ada tiga tahap dalam penyelesaian konflik yaitu peace making (mempertemukan atau merekonsiliasi),

peace

keeping

(menghentikan atau mengurangi intervensi militer) dan peace building (implementasi perubahan atau rekonstruksi sosial).

Pertama, peace-making yakni proses yang tujuannya mempertemukan atau merekonsiliasikan sikap politik dan strategi dari pihak yang berkonflik melalui mediasi, negosiasi, arbitrasi. Bila dikaitkan dengan kasus ini pihak yang berkonflik akan dipertemukan untuk menyelesaikan konflik dengan cara yang damai. Hal ini dilakukan dengan menghadirkan pihak ketiga sebagai penengah, namun pihak ketiga tersebut tidak mempunyai hak untuk menentukan keputusan yang diambil. Pihak ketiga hanya menengahi apabila terjadi suasana yang memanas antara pihak yang berkonflik saat sedang berunding.

Kedua, peace keeping yaitu proses menghentikan atau mengurangi aksi kekerasan melalui intervensi militer yang seharusnya menjalankan peran netral sebagai penjaga perdamaian. Menurut definisi ini, konflik yang terjadi antara pemerintah Thailand dengan gerakan aliansi separatisme Thailand dikesampingkan karena upaya perdamaian yang dilakukan tanpa intervensi militer manapun. Hal ini sesuai dengan ASEAN Way, yaitu kebiasaan ASEAN dalam menyelesaikan persoalan dengan mengedepankan upaya diplomasi, tekanan, 
dan pencegahan tanpa melibatkan aksi militer asing (Marsilamani, 2014).

Ketiga, peace building yaitu proses implementasi perubahan atau rekonstruksi sosial, politik dan ekonomi demi terciptanya perdamaian. Melalui proses peace building segala negative peace (the absence of violence) berubah menjadi positive peace dimana masyarakat dapat merekan keadilan dan kesejahteraan. Berdasarkan tahap-tahap penyelesaian konflik di atas, Malaysia yang berperan sebagai fasilitator dalam penyelesaian konflik Thailand Selatan, telah melakukan tahap-tahap penyelesaian konflik seperti tahap peace making dan peace building sebagai upaya Malaysia dalam proses konsolidasi perdamaian di Thailand Selatan.

Dalam konflik ini peran fasilitator Malaysia berupaya untuk mempertemukan kedua belah pihak yang terlibat konflik yaitu pemerintah Thailand dan gerakan aliansi separatisme Thailand Selatan untuk berunding menyelesaikan masalah yang ada yang bertujuan agar kedua belah pihak menemukan solusi untuk menyelesaikan konflik yang ada. Adapun rangkaian upaya yang dilakukan Malaysia dalam upaya penyelesaian konflik dimulai pada tahun 2005.

Sebelum itu pada tahun 2004 terdapat dua peristiwa yang menguncang
Thailand Selatan yaitu serangan terhadap Masjid Krue Se dan insiden kekerasan di Tak Bai, Narathiwat. Serangan terhadap Masjid Krue Se terjadi pada tanggal 28 April 2004 ketika militer Thailand menyerang Masjid Krue Se yang ada di Pattani dan membantai sekelompok orang yang di duga pemberontak. Korban tewas saat itu mencapai 37 orang yang berasal dari militant. Sementara itu, insiden kekerasan di Tak Bai terjadi pada 25 Oktober 2004. Serangan dimulai ketika Distrik Tak Bai diserang oleh sekelompok orang. Beberapa orang dipenjarakan oleh polisi Thailand terkait serangan tersebut. Hal ini tentunya memicu demonstrasi masyarakat Thailand Selatan di luar kantor polisi distrik. Polisi

Thailand menanggapi demonstrasi tersebut dengan cara kekerasan. Peristiwa tersebut menyebabkan terjadinya kerusuhan yang menewaskan 86 orang di Thailand Selatan. Sejumlah 1.300 orang di tangkap dan dibawa ke Tak Bai ke kamp militer Pattani (L.Gross, 2007:79). Enam orang meninggal ditempat kejadian dan 78 meninggal karena kekurangan oksigen ketika berada di dalam truk saat perjalanan menuju kamp militer. Kejadian ini menimbulkan kontroversi dan spekulasi yang mulai bermunculan di antaranya tuduhan kekerasan yang berlebihan, metode yang terlalu keras, serta 
pelanggaran hak asasi manusia. Puncak dari peristiwa ini terjadi pada tahun 2005 ketika pemerintahan Thailand menerapkan status darurat militer di wilayah Thailand Selatan. Hal ini membuat masyarakat Thailand Selatan merasa khawatir dan takut.

Pada 30 Agustus 2005, 131 masyarakat muslim Thailand Selatan menyebrangi perbatasan dan masuk ke wilayah Kelantan, Malaysia untuk menghindari konflik. Pada masa itu Dr. Tun Mahathir Muhammad yang sedang menjabat pada masa itu memberikan pandangannya kepada gerakan aliansi separatisme untuk perdamaian dan penyelesaian konflik di Thailand Selatan (Fuston, 2010: 248). Selang beberapa bulan pertemuan tersebut, pada bulan Oktober 2005 mantan Perdana Menteri Thailand Anand Panyarachun menemui Tun Mahathir Muhammad di Putrajaya untuk mendapatkan perspektif Malaysia dalam menangani konflik di Thailand Selatan.

Sebelumnya, atas undangan Anand Panyarachun, Tun Dr Mahathir Mohamad telah menemui Raja Bhumibol Adulyadej di Bangkok, Thailand. Baginda merestui peran Mahathir sebagai penengah dan merupakan tokoh yang berwibawa yang mewakili pemimpin Islam moderat. Anand Panyarachun merupakan ketua National
Reconciliation Council (NRC) yang ditunjuk oleh Perdana Menteri Thaksin Shinawatra ketika itu. Tujuannya menemukan metode terbaik mendamaikan daerah mayoritas Islam di Yala, Narathiwat dan Pattani. Isi draf rencana perdamaiannya adalah kelompok separatisme harus menggugurkan tuntutannya untuk merdeka, sebagai balasnya mereka diberikan pengampunan, pembangunan ekonomi yang lebih baik, alokasi dana yang lebih banyakuntuk pembangunan di wilayah Thailand Selatan dan penggunaan bahasa Melayu di sekolah-sekolah yang berada di wilayah Thailand Selatan (Fuston, 2010: 248).

\section{Kebijakan Luar Negeri Pemerintahan Najib Razak ditahun 2013}

Atas permintaan resmi Thailand kepada Malaysia, Malaysia diminta untuk memfasilitasi pembicaraan antara kelompok-kelompok Muslim Pattani yang beroperasi di Thailand maupun di Malaysia. Untuk tahap awal Malaysia berhasil mempertemukan kelompok Muslim Pattani untuk berbicara secara langsung dengan pemerintah Thailand yang ditandatangani di Kuala Lumpur pada tanggal 28 Februari 2013 lalu (BBC, 2013).Kesepakatan ini ditandatangani di Malaysia bersama Barisan Revolusi Nasional (BRN), salah satu dari beberapa kelompok pemberontak yang beroperasi di 
Thailand Selatan. Perdana Menteri

Yingluck Shinawatra bersama Perdana Menteri Malaysia Najib Razak kemudian menggelar pertemuan di Kuala Lumpur pada Kamis tanggal 28 Februari 2013.

Pertemuan ini akan membahas pemberontakan di kawasan perbatasan kedua negara. Malaysia yang bertindak sebagai fasilitator dalam negosiasi antara pemerintah Thailand dengan pemberontak Muslim dan menjadi tuan rumah dalam setiap pembicaraan damai antar kedua belah pihak. Dokumen kesepakatan damai yang ditandatangani di Kuala Lumpur ini disebut sebagai awal dari sebuah proses dialog. Kesepakatan ini menandakan sebuah terobosan besar dalam upaya untuk mengakhiri kekerasan yang meningkat dalam beberapa bulan terakhir.

Sekretaris jenderal Badan Keamanan Nasional Thailand Paradorn Pattanatabutr, yang menandatangani kesepakatan ini mengatakan, sebagai upaya lain dari pemerintah untuk mengatasi kerusuhan dan tidak berarti mengakhiri konflik secepatnya. Sementara Hassan Taib, perwakilan BRN yang menandatangani mengatakan bahwa "Terimakasih Allah, kami akan melakukan yang terbaik untuk memecahkan masalah. Kami akan meminta rakyat kami untuk bekerja sama mengatasi masalah.” Dengan ditandatanganinya dokumen kesepakatan damai ini memberikan harapan kepada masing-masing pihak yang bertikai akan lahirnya perdamaian dan keadilan di wilayah Thailand Selatan. Setelah perjanjian damai yang ditandatangani pada tanggal 28 Februari 2013 yang lalu. Pihak Thailand dan pihak pemberontak sepakat untuk melakukan dialog damai lanjutan. Dialog damai tersebut dinamakan dialog damai KL (Kuala Lumpur) yang akan dilaksanakan di Kuala Lumpur Malaysia.

$$
\text { Pada dialog damai KL }
$$
diselenggarakan pada tiga kali yaitu pada bulan Maret, April dan Juli. Proses dialog Damai KL tidak hanya diikuti secara cermat oleh masyarakat regional tapi juga dipantau pengamat hak asasi manusia internasional. Sejak ditandatangani konsensus umum antar pemerintah Thailand dan wakil para pejuang (BRN), kedua pihak duduk di meja rundingan sebanyak 3 kali (Maret, April dan Juli 2013). Di luar pertemuan formal itu, kedua belah pihak yaitu Delegasi Thailandyang dipimpin oleh Sekertaris Jenderal Dewan Keamanan Nasional, Paradorn Pattanatabut sementara delegasi BRN diketuai Ustaz Hassan Taib beberapa kali bertemu dengan fasilitator dari Malaysia yaitu Dato Zamzamin.

Proses Dialog Damai KL mulai tampak ada sedikit keraguan setelah kedua belah pihak tidak mematuhi kesepakatan 
untuk mengurangi kekerasan selama 40 hari dari awal Ramadan 2013, yang dikenali dengan Inisiatif Damai Ramadan (Ramadhan Peace Initiative). Pada tahap awal, inisiatif yang dibuat sepihak oleh fasilitator ini dinilai cukup baik, tetapi akhirnya berantakan. Hal ini disebabkan karena dalam inisiatif yang diumumkan pada 12 Juli 2013 itu disebutkan bahwa masing-masing pihak baik para pejuang bersenjata pembebasan Patani (BRN) dan tentara Thailand harus menahan diri dengan mengurangi tindak kekerasan. Menanggapi hasrat baik tersebut, BRN menyambut dengan menyatakan, mereka tidak hanya akan mengurangi kekerasan bahkan akan berhenti selama bulan Ramadan. Tentu saja dengan syarat, tentara pemerintah harus ditarik balik ke kamp. Selama tempo tersebut tentara Thailand tidak boleh lagi berkeliaran di tengah-tengah masyarakat Melayu di wilayah Thailand Selatan. Namun dalam minggu pertama saja aparat keamanan sudah menembak mati beberapa pemuda aktivis perjuangan.

Hal ini disebabkan karena terdapat kelemahan dalam inisiatif tersebut. Di antaranya tidak disebutkan secara jelas siapa yang akan memantau keadaan di lapangan selama gencatan senjata tersebut. Masyarakat juga tidak menerima informasi yang tepat tentang apa yang disepakati.
Seperti jika ada pelanggaran harus diadukan ke pihak mana. Karena tidak tahan diserang sepihak, akhirnya pejuang bersenjata membalas dengan menyerang anggota keamanan Thailand. Inisiatif Damai Ramadan pun bubar dengan masing-masing pihak saling menyalahkan. Pada saat perundingan pihak BRN aktif mengajukan 5 Tuntutan sejak awal. Namun pihak Thailand merasa keberatan dengan tuntutan tersebut.

Tuntutan yang dirasakan paling berat oleh pihak Thailand di antaranya disebutkan bahwa Bangkok harus mengakui ketuanan bangsa Melayu di atas bumi Patani yang dijajah secara mutlak sejak 1902. Yang tidak kalah penting, pihak pemberontak menginginkan proses dialog damai harus mendapat dukungan dari parlemen Thailand dan dialog damai harus menjadi salah agenda nasional. Juga harus mengangkat status Malaysia menjadi mediator, bukan hanya sekadar fasilitator. Wakil-wakil badan atau organisasi internasional seperti Asean dan LSM asing harus dilibatkan sebagai pengamat. BRN harus diakui sebagai gerakan pembebasan dan semua tersangka ditahan karena serangan teror harus dibebaskan dan penangkapan kepada warga Thailand Selatan yang dianggap sebagai pemberontak harus dihentikan. Semua yang diminta BRN itu ditolak mentah- 
mentah oleh Thailand. Karena menurut pihak Thailand, yang akan dibicarakan dalam dialog tersebut adalah masalah internal negara dan tidak harus mellibatkan pihak luar.Pada tanggal 2 September 2013 kembali diadakan perundingan antara pemerintah Thailand dan pemberontak Thailand Selatan di Kuala Lumpur. Namun pembicaraan pada 2 September yang difasilitasi oleh Malaysia tersebut berakhir tanpa terobosan dan tanpa kesepakatan (Ahram, 2016).

\section{Kebijakan Luar Negeri Pemerintahan} Najib Razak ditahun 2016

Pada tanggal 27 April 2016 delegasi Thailand bertemu di Kuala Lumpur dengan konsultan yang mewakili kelompok separatisme bersenjata Thailand Selatan dalam upaya untuk melanjutkan pembicaraan damai secara resmi, namun pertemuan itu berakhir tanpa perkembangan selanjutnya (Rashid, 2016). Pada tanggal 10 September 2016 Perdana Menteri Malaysia dan Thailand berikrar di Bangkok bahwa pemerintah Thailand dan pemerintah Malaysia akan terus bekerja bersama-sama untuk menyelesaikan konflik di Thailand Selatan serta mengukuhkan hubungan keamanan lintasbatas diperbatasan kedua negara. Pernyataan itu dibuat seminggu setelah Malaysia menjadi tuan rumah putaran terbaru perundingan tidak resmi antara pemerintah Thailand dan pemberontak Thailand Selatan, meskipun terjadinya serangkaian pengeboman mematikan di Thailand Selatan sejak beberapa bulan lalu, yang diduga dilakukan oleh kelompok pemberontak di wilayah Thailand Selatan .

Kepentingan kedua negara saling berkait. Stabilitas, dari segi keamanan dan dari segi kemakmuran, kepentingan dan masa depan kedua negara adalah tidak bisa dipisahkan, kata Perdana Menteri Malaysia Najib Razak pada sidang berita. Dalam konteks keamanan, Malaysia terus siap untuk memainkan peran sebagai fasilitator dalam membantu dalam proses damai di Thailand Selatan. Saya sekali lagi menegaskan komitmen kami dan pemahaman kami bahwa ini adalah satu hal domestik Thailand dan akan meneruskannya berdasarkan kerangka kerja dan pedoman yang diberikan oleh pemerintah Thailand (Somchai, 2016). Kami telah sepakat dalam masalah keamanan, perdagangan, ekonomi perbatasan serta negosiasi damai bagi wilayah Selatan, kata Perdana Menteri Thailand Prayuth Chan-o-cha pada Benarnews.com.

Kedua perdana menteri itu mengatakan mereka setuju bahwa negara mereka akan berbagi informasi intelijen dalam bekerjasama memerangi terorisme 
global dan kejahatan transnasional seperti perdagangan manusia dan penyelundupan. Wilayah perbatasan antara Malaysia dan Thailand memang dikenal sebagai daerah yang banyak dipenuhi oleh aktivitas kriminal, dan pemberontak Thailand Selatan sering keluar masuk melaluinya. Kedua Perdana Menteri setuju untuk bergerak maju dengan menjelajahi perencanaan bersama untuk membangun tembok atau pagar untuk mempertahan perbatasan antar kedua negara.

Selain itu usaha yang diambil Najib Razak yaitu peace building Pada tanggal 10 September 2016, Perdana Menteri Thailand Mengunjungi Malaysia untuk membicarakan upaya proses perdamaian di Thailand Selatan. Pada pertemuan tersebut dibicarkan mengenai solusi konflik untuk wilayah Thailand Selatan. Salah satu solusinya adalah dengan meningkatkan kualitas hidup dari masyarakat Thailand Selatan yaitu dengan memberikan pelatihan kejuruan baik dalam bidang pariwisata, otomotif dan perhotelan kepada pemuda yang berada di wilayah Thailand Selatan.

Adanya transfer ilmu dengan mengirimkan guru-guru kejuruan ke wilayah Thailand Selatan untuk transfer ilmu serta melakukan kerjasama dengan sekolah-sekolah yang ada di Malaysia untuk mengadakan program pertukaran pelajar kejuruan. Selain itu adanya kerjasama antara pemerintah Malaysia dan Thailand untuk memberikan pengajaran agama dalam bidang akademik. Hal ini dilakukan dengan cara transfer ilmu dengan cara mengirim guru-guru agama yang ada di Thailand Selatan untuk dilatih di Malaysia untuk memperdalam ilmu agama dan kualitas pengajaran keagamaan, serta adanya pertukaran pelajar antar sekolah yang ada di Thailand Selatan dengan yang ada di Malaysia. Najib berjanji bahwa Malaysia akan terus membantu dari segi pelatihan kejuruan untuk anak-anak muda di Thailand Selatan dan Perdana Menteri Prayuth telah meminta kami untuk membantu dalam hal sekolah-sekolah agama di Thailand Selatan sehingga mereka dapat belajar akademik dan subjek keagamaan.

Sebagai sesama negara anggota ASEAN, Malaysia dan Thailand menginginkan adanya stabilitas politik dan keamanan di wilayah perbatasan di kedua negara tersebut. Wilayah Thailand Selatan dan Utara Malaysia merupakan wilayah basis dari Muslim Pattani yang secara tidak langsung akan juga mengganggu hubungan bilateral kedua negara tersebut jika tidak diselesaikan dengan baik. Seyogyanya kesepakatan perundingan antara Muslim Pattani dan Pemerintah Thailand yang akan membicarakan proses 
perdamaian akan menjadi sebuah kesepakatan bersejarah tidak saja bagi Muslim Pattani dan Pemerintah Thailand juga akan memiliki dampak bagi stabilitas ASEAN pada umumnya.

\section{Kesimpulan}

Realitas sebuah negara Pattani merdeka adalah suatu ide yang tidak dapat direalisasikan, karena usaha untuk mendapatkannya tidak pernah dilakukan secara profesional. Tindakan pembakaran, pemboman dan pembunuhan secara hit and run jelas tidak menunjukkan usaha yang terencana dan matang untuk mewujudkan ide tersebut. Sehingga rumusan dan ide sebuah negara merdeka ini adalah aspirasi yang bersifat utopian. Sebaliknya, pihak gerakan separatisme ingin mendapatkan kekuasaan dan melibatkan diri dalam menentukan pembangunan sosio-ekonomi dan politik di Thailand Selatan.

Gerakan aliansiseparatisme Selatan Thailand gagal menggunakan legitimasi sejarah Pattani yang berubah dari Melayu Muslim menjadi bagian wilayah dalam negara Thai Buddha. Bagi orang-orang Pattani, wilayah Selatan Thailand yang bekas kerajan Pattani adalah tanah yang diperjuangkan, sedangkan bagi kerajaan Thai wilayah tersebut merupakan wilayahwilayah yang telah dikuasai. Legitimasi sejarah yang tidak diterjemahkan dalam konteks legitimasi politik ini merupakan satu faktor kelemahan dan kegagalan gerakan aliansiseparatisme Selatan Thailand jika dibandingkan dengan perjuangan Bangsa Moro di Selatan Philipina, gerakan Aceh Merdeka dan Timor Leste. Insiden dan krisis politik di selatan Thailand ketika ini hanya pada tahap lokal.

Kebijakan kerajaan yang efektif serta kerjasama di antara kerajaan dan pihak-pihak yang terlibat konflik untuk mencari jalan penyelesaian pastinya dapat membantu krisis ini ditangani sebelum berkembang menjadi lebih besar dan bersifat global. Salah satu solusi penyelesaiannya adalah dengan meningkatkan kualitas hidup dari masyarakat Thailand Selatan dengan memberikan pelatihan kejuruan baik dalam bidang pariwisata, otomotif dan perhotelan kepada anak-anak muda yang berada di wilayah Thailand Selatan. Selain itu adanya kerjasama antara pemerintah Malaysia dan Thailand untuk memberikan pengajaran agama dalam bidang akademik dan adanya pertukaran pelajar antar sekolah yang ada di Thailand Selatan dengan yang ada di Malaysia. Malaysia akan terus membantu dari segi pelatihan kejuruan untuk anak-anak muda di Thailand Selatan dan Perdana Menteri 
Prayuth telah meminta kami untuk membantu dalam hal sekolah-sekolah agama di Thailand Selatan sehingga mereka dapat belajar akademik dan subjek keagamaan. Hingga berakhirnya kepemimpinan Najib Razak dalam

\section{Referensi}

Melvin, Neil J. (2007). Conflict in Southern Thailand: Islamism, Violence and the State in The Pattani Insuregency Policy Paper No.20.Sweden: SIPRI (Stockholm International Peace Research Institute).

Andaya, Barbara Watson. Leonard Y. Andaya.(2001). A History of Malaysia Edisi Kedua. Honolulu : University of Hawaii Press.

A.Malek,Mohd Zamberi.(1993). Umat Islam Pattani Sejarah dan Politik. Selangor Darul Ehsan : Hizbi Syah Alam.

Goldstein, Joshua. (1999). International Relations. New York: Longman

James N. Rosenau. (1996). International Poitics and Foreign Policy: A Reader in Research and Theory. New York : The Free Press.

Yuniarto, Paulus Rudolf. (2005). Minoritas Muslim Thailand: Asimilasi, Perlawanan Budaya dan Akar Gerakan Separatisme Volume penyelesaian konflik akhirnya menuju ke tahap rekonsiliasi dan mulai menunjukkan titik terang konsolidasi antara pemerintah Thailand dengan gerakan aliansi separatisme Thailand Selatan.

\section{No. 1. Jakarta: Jurnal} Masyarakat dan Budaya.

Pitsuwan, Surin. (1989)Islam di MuangThai: Nasionalisme Melayu Masyarakat Pattani. Jakarta: LP3ES. Funston, Jhon. (2006).Thailand's Southern Fires: The Malaysian Factor. Research School of Pasific and Asian Studies (RSPAS), Canberra: Australian National University.

Srisompob, Jitpiromsri. Pantyasak Sobhonvasu. (2006). Unpacking Thailand's Southern Conflict: The Poverty of Structural Explanations. Routledge: Critical Asian Studies $38: 1$.

Wibisono, Wimpi. (2007). Malaysia Khawatirkan Status Darurat Thailand Selatan. Jakarta: Republika.

Gross,Max L. (2007). A Muslim Archipelago: Islam and Politics in Southeast Asia. Washington DC: National Defense Intelligence College. 
Fuston, John. (2010).“Malaysia and Thailand Southern Conflict: Reconciling Security and Ethnicity,"Contemporary Southeast Asia: A Journal of International and Strategic Affairs 32, No. 2.

\section{Website}

Ervan, Handoko.(2016).Sekilas Mengenal Keluarga Kerajaan Thailand diakses melalui

https://internasional.kompas.com/rea d/2016/10/14/11224641/sekilas.men genal.keluarga.kerajaan. Thailand?pa ge=all pada tanggal 10 Maret 2019 pukul 18.28 WIB

Thai Embassy. (2017). ชาวมุสลิมในประเทศไทย (Muslim in Thailand) diakses melalui

http://www.Thaiembassy.org/riyadh/ th/organize pada tanggal 10 Maret 2019 pukul 19.25 WIB

Akbar, Aulia. (2011). Yingluck Utamakan

Keamanan Thailand Selatan diakses melalui

https://news.okezone.com/read/2011/ 08/23/411/495201/yingluck-

utamakan-keamanan-thailand-selatan pada tanggal 12 Maret pukul 18.50 WIB

Tempo Indonesia. (2011). ThailandMalaysia Petakan Atasi Ketegangan di Thailand Selatan diakses melalui http://www.tempo.co.id/hg/luarneger i/2007/03/23/brk,2007032396136,id. html pada tanggal 13 Maret 2019 pukul 17.25 WIB

Oxford Research. (2019). Peace making, Peace keeping and Peace building diakses melalui http://oxfordre.com/internationalstud ies/view/10.1093/acrefore/97801908 46626.001.0001/acrefore9780190846626-e-274 pada tanggal 13 Maret 2019 pukul 18.11 WIB

BBC Indonesia. (2013). Thailand Menyepakati Perdamaian dengan Pemberontak di akses melalui http://www.bbc.com/indonesia/dunia /2013/02/130228_thailand_militan. pada tanggal 13 Maret 2019 pukul 18.02 WIB

Ahram. (2016). Thailand Akan Lanjutkan Pembicaraan Damai dengan Pejuang Muslim Patanidi akses melalui http://www.voaislam.com/read/worldnews/2016/12/08/47748/thailandakan-lanjutkanpembicaraan-damaidengan-pejuang-muslimpatani/\#sthash.otJundGp.dpuf. pada tanggal 14 Maret pukul 14.47 WIB.

Rashid, Razlan. (2016). Pegawai Thai, Kumpulan Pemisah Selatan Bertemu di Malaysia diakses melalui http://www.benarnews.org/malay/ber ita/my-th-peacetalk-160427- 
04272016180719.html pada tanggal

14 Maret 2019 pukul 17.56 WIB.

Kwankijsawet, Somchai. (2016).

Malaysia,Thailand Sahkan Lagi

Komitmen Terhadap Proses Damai

\section{Selatan}

diakses

2019

http://www.benarnews.org/malay/ber

ita/deep-south-

09102016082010.html pada tanggal

14 Maret 2019 Pukul 18.23 WIB. 